\title{
Evaluation of Mandarin Cultivars on Different Root Stocks-A Review
}

\author{
Sukhdip Singh, Jatinder Singh and Anis Mirza* \\ School of Agriculture, Department of HorticultureLovely Professional University Phagwara, \\ Jalandhar-Delhi G.T. Road (NH-1), Phagwara-144411, Punjab (India) \\ *Corresponding author
}

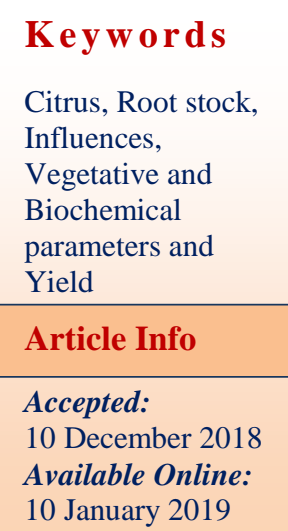

\section{Keywords}

Citrus, Root stock, Unfluences, Yield

\section{A B S T R A C T}

In Punjab sweet orange and commercial mandarin cultivars are generally grafted or budded on rootstock of rough lemon. This rootstock is highly vulnerable to phytophthora (foot rot) like diseases. Moreover, quality of kinnow plants budded or grafted on an effective rootstock should have good compatibility between both, scion and rootstock besides decent tolerance against predominant edaphic and environmental circumstances. The rootstocks have major effect in tree vigour, quality of the fruit, juice quality, yield including tolerance to salt and cold conditions. The monopolized cultivation of this cultivar scion grafted over rough lemon requires a substituted rootstock for advanced yield/good returns along with lengthier productive life of the tree. Among numerous factors answerable for citrus decline, rootstocks may be considered as major contributor regarding climatic conditions. Nowadays rootstocks associated with this problem in Citriculture industry have presumed a great implication. Every country having citrus cultivation is facing this burning problem. At one time particular rootstock seems very appropriate but may completely fail in future including monoculture may be the basic problem of the all Citrus growing estates. Hence selection of appropriate rootstock for scion cultivar may lead to the success or failure of the citrus plantation. Till now it was reported that Volkamer lemon, Citrumello 4475 along with Brazilian sour orange were the consistent rootstocks for citrus industry of the Punjab. Present review will contribute in selecting appropriate rootstock to overcome dependability of one particular rootstock in citrus industry of Punjab to overcome the future problems.

\section{Introduction}

The position of citrus fruit to agriculture and economy of the world is established by largescale production and wide cultivation. It is an important member of the family Rutaceae. Several species of citrus plant are supposed to be indigenous to tropical and sub-tropical regions of Asia and Malaya archipelago
(Hooker, 1872). Citrus is a third most important fruit crop of India. But in Punjab it is at no.1 position. Among various citrus cultivars, Kinnow fruit is the most significant and having major shares of total citrus production in India. Choice of rootstock is important aspect in fruit crops especially in citrus because scion cultivars respond variously to growth, quality and nutrients 
buildup when grown on varied rootstocks. Sometimes plant nutrient concentrations may fluctuate even if they are grown under same conditions (Bergmann, 1992). It was revealed that Rangpur lime rootstock induces high yield when sweet orange proliferated on the same. Size of the tree also decreases along with production of good quality fruit but susceptible to foot rot and blight disease but accepting soil salinity and tristeza etc. Lima (1992) explained that plants budded on Rangpur lime were vigorous ingrowth and comparable to trees budded on Rough lemon. Plants were large in size, but cold tolerance was minimum. Moreover, these were prone to blight disease. He also described various strains of Rangpur lime viz. Brazil Orange, Florida Rangpur lime, Brazil Rangpur, Sylhet lime, Philippian Red Lime, Nemytengs, Taxas Rangpur Lime, PinkFleshed Lime etc. Niaz and Chattha (1994) recorded that 50 seeds per fruit in case of Rubidoxtrifoliate orange showed poor germination in contrast to Roughlemon rootstock which gave fruit with less seeds i.e. 26 seeds per fruit with outstanding germination. Niaz et al., (1994) revealed that Kinnow and Feutrell's early budded on rootstock of Rough lemon is more prolific than other stocks but this is susceptible to Phytophthora disease. Further, fruit quality was very poor in case of this rootstock. Singh et al., (2002) revealed that Kinnow trees vigour and grown on Cleopatra mandarin was decent and tree size was standard. Fruit quality on was also excellent. Broadbent and Sarooshi (1993) described that Rough lemon (Citrus jembhiri, Lush) used as rootstock for various citrus cultivars in Australia, India and many other countries. Plants budded on Rough lemon were usually vigorous having good fruit size and poor quality of juices when compared to different used rootstocks. Snokar et al., (2001) described that experiments conducted at Montgomery (Sahiwal), Pakistan and disclosed that Rough lemon is the fine stroot stock for Blood Red malta while for other mandarins and oranges, Kharnakhatta is the superlative. They further supported that Rough lemon is commonly widely used rootstock followed by Kharnakhatta. Likewise, Sharma (2006) described that trees grafted on rootstock of Rough lemon were vigorous and gave high yield but with poor quality. However, Sharma and Srivastava (2004) revealed that Rough lemon can be cultivated on various soils and is highly sensitive to cold conditions. At the same time, Rangpurlime is well adjustable in saline soils and cool environment. Overall, rootstock of Rangpurlime is very poor seedier $(7$ seeds per fruit) and Rough lemon is much better seedier (32seeds per fruit). In another experiment (Anon et al., 2007) kinnow was grafted on three different rootstocks viz. Kinnow, Rangpur lime and Rough lemon. It reported that Kinnow trees grafted on rootstock of Rough lemon were more vigorous growth in height and spread while plants grafted on rootstock of Rangpur lime achieved minimum plant height and spread. Volkamer lemon is a capable rootstock for Kinnow under the dry climate conditions.

Environmental effects on rootstocks have been well defined but the variation is due to weather conditions and intercultural practices. The climate of the Punjab is very harsh during summer and vigorous rootstock is obligatory to sustain the flushes of spring. So according to previous theories Volkamer lemon showed quite satisfactory results and could be used as a supernumerary rootstock for existing Rough lemon as rootstock variety in Citriculture industry.

\section{Effect of stock scion combination on vegetative parameters of citrus fruit}

\section{Plant height/tree size}

Georgiou (2009) established that the most capable rootstocks that may substitute sour 
orange for local lemon variety 'Lapithkiotiki' under Cyprus conditions are Volkameriana, Yuma Ponderosa lemon, C. macrophylla and Citremon 1449. Dubey and Sharma (2016) discovered that plant height was more on rough lemon and RLC-4 rootstocks. Tazima et al., (2013) revealed that maximum plant growth for the trees on 'Cleopatra' mandarin and 'Caipira DAC' sweet orange was obtained as compare to 'Volkamer' lemon and trifoliate orange trees. Shafieizargar et al., (2012) explained that the rootstocks have noteworthy effects on most of the calculated characters, indicating that tree height of 'Queen' orange can be controlled by using appropriate rootstocks. They discovered that Volkamer lemon is a better rootstock for 'Queen' orange. Espinoza-Nunez et al., (2011) discovered that rootstocks affected plant vigor, particularly 'Flying Dragon' trifoliate, which declined tree height by $47 \%$ in contrast to the 'Rangpur' lime. Legua et al., (2011) found that rootstock influenced fruit quality variables. $C$. macrophylla and C. volkameriana appeared to encourage the bigger tree size. Jaskarni et al., (2002) revealed that diploid trees of kinnow trees were more lengthy than tetraploid trees. Cimen et al., (2014) revealed that plants on Tuzcu No.31, 31 and Gou Tou sour orange rootstocks were the least affected regarding plant growth. Forner-Giner et al., (2010) established that trees on rootstock $C$. volkameriana were the largest followed by trees on rootstock Carrizo citrange.

\section{Plant spread}

Cantuarias-Aviles et al., (2010) established that 'Flying Dragon' trifoliate showed a distinct result over the 'Okitsu' mandarin trees performance, inducing lower canopy size. Dubey and Sharma (2016) discovered that canopy amount was higher on rough lemon and RLC-4 rootstocks while girth was higher on Billikichlli and RLC-4 rootstocks. Forner-Giner et al., (2010) revealed that trees on $\mathrm{C}-13$ hybrid selection were proficient in yield m-3 of canopy spread. Jaskarni et al., (2002) detailed that diploid Kinnow trees were larger in spread than tetraploid. Singh et al., (2002) revealed that Rangpur lime root stock reduced size of the tree. Rootstocks may affect the capability of plants to take up water, nutrients etc. Kumar et al., (1994) reported that dynamic rootstocks are required under arid environmental conditions, to give a boost to citrus trees.

\section{Scion girth}

Jaskarni et al., (2002) discovered that diploid kinnow trees attained more stem girth than tetraploid ones. Shah et al., (2016) established that Meyer lemon when grafted on sour orange rootstock affected scion diameter and scion length.

\section{Effect of combination of rootstock and scion on Chlorophyll content}

Cimen et al., (2014) found maximum decrease in the leaf chlorophyll content in (-) Fe plants of Navelina on trifoliate (local) and C-35 citrange. Performance of citrus rootstocks and their effects on nutrient levels of leaf have been considered for dissimilar climatic conditions across the world (Fallahi and Rodney, 1992; Georgiou, 2002; Smith et al., 2004; Srivastav et al., 2005; Toplu et al., 2012).

\section{Effect of combination of rootstock and scion on fruit yield}

Dubey and Sharma (2016) established that rootstock RLC-4 yielded heaviest (weightwise) fruits. Cantuarias-Aviles et al., (2010) found that 'Flying Dragon' trifoliate had a distinctive result over the 'Okitsu' mandarin performance. This kind of combination had more yield potential whereas in 'Sun Chu Sha Kat' and 'Sunki' mandarins 
and the 'Orlando' tangelo showed lower yield efficiency. Georgiou (2009) revealed that the most proficient rootstocks that may substitute sour orange for lemon variety 'Lapithkiotiki' under Cyprus conditions are Yuma Ponderosa lemon, Volkameriana, Citremon 1449 and $C$. macrophylla. Shafieizargar et al., (2012) established that rootstocks have significant effects on most of parameters, indicating that tree yield of 'Queen' orange can be controlled by appropriate assortment of rootstock. They found that Volkamer lemon is a best rootstock for grafting of 'Queen' orange. Zekri et al., (2004) found highest fruit weight on trees budded on rough lemon, Volkamer lemon and Citrus marophylla, while the least fruit weight wasrecorded on trees budded on Sour orange and Cleopatra mandarin. Hussain et al., (2013) found advanced performance of Carrizo citrange while evaluating common clementine for yield on nine rootstocks. They found that Clementine was incompatible on Da Hong Pao mandarin and Gou Tou sour orange. Yildiz et al., (2013) publicized that 'Troyer' citrange had low yield than those budded on other rootstocks, whereas yield of 'Rhode Red Valencia' and 'Valencia Late' orange trees on 'Carrizo' citrange were more than those on 'Troyer' citrange, likewise. Legua et al., (2011) found that rootstock considerably affected fruit quality. They recorded that $C$. macrophylla and $C$. volkameriana appeared to induce the heaviest fruit weight. Zekri (2000) recorded that fruit yield was the highest for volkamer lemon. Georgiou (2000) also observed maximum yield from the trees on Brazilian sour orange and Volkamariana rootstock.

\section{Fruit size}

Zekri et al., (2004) reported heavier fruits on trees budded on rough lemon, Citrus marophylla and Volkamer lemon while the smaller fruits were found on trees budded on Sour orange and Cleopatra mandarin.
McCollum et al., (2017) revealed that rootstock effects on fruit size were noteworthy. 'Sour orange' and 'Swingle' yielded the largest fruits, whereas US-897 formed the smallest sized fruits. Zekri (2000) reported that highest fruit sizes were obtained for Volkamer lemon and the smallest for Cleopatra mandarin. The fruit size an important feature for both producers as well consumers. Medium to large sized fruit contribute profitable returns (Hussain et al., 2013). In a study Dubey and Sharma (2016) produced medium to large sized fruits being biggest fruits on RLC-4 rootstock except rough lemon and Billikichlli. Analogous findings were submitted by Bielicki et al., (2006).

\section{Fruit weight}

Legua et al., (2011) established that rootstock significantly affected fruit quality variables. C. macrophylla and C. volkameriana would appear to encourage the highest fruit weight. Jaskarni et al., (2002) discovered that diploid kinnow trees were much better than tetraploid as for as fruit weight was concerned.

\section{Fruit yield}

Legua et al., (2011) considered Cleopatra mandarin and Gou TouChen to be the most reviving rootstocks for 'Lane Late' where as plants on $C$. macrophylla rootstock gave the maximum yield. Tazima et al., (2013) obtained highest yield in plants of 'Okitsu' Satsuma mandarin on 'Swingle' citrumelo whereas 'Rangpur' lime and 'Volkamer' lemon resulted in the lower yields.

Georgiou (2009) observed that most proficient rootstocks that may be replaced with sour orange for local lemon variety 'Lapithkiotiki' under Cyprus conditions were, Yuma Ponderosa lemon, Volkameriana, Citremon 1449 and C. macrophylla. Castle et 
al., (2010) found that fruit yield was associated with tree height regardless of deviations among rootstocks but performance of trees on rootstocks with moderately low productivity/tree, like those on Kinkoji and C35 citrange, would be identical those on sturdier rootstocks. Mademba-Sy et al., (2012) found that yields were 0.5 to 2.8 times greater than those of the same cultivar on the standard rootstock when trees were grafted on Flying Dragon trifoliate orange. Dubey and Sharma (2016) stated that RLC-4 root stock had performed well over other rootstocks regarding fruiting density and trailed by Attani-2, rough lemon and Karna Khatta, although it was bottommost on Troyer citrange.

\section{d) Peel/Rind thickness}

Jaskarni et al., (2002) discovered that diploid kinnow trees were better than tetraploid regarding rind thickness. McCollum et al., (2017) reported that rind thickness was maximum in 'Sour Orange' but early in the season and it was not so at the end of the season.

\section{e) Juice content (\%)}

Dubey and Sharma (2016) revealed that rough lemon and RLC-4 had considerably yielded higher percentage of juice. Tazima et al., (2013) revealed that 'Carrizo' and trifoliate orange produced the premium juice content. Zekri et al., (2004) found trees on rough lemon that those fruit trees having lesser juice content. But Valencia trees produced high juice content. Yildiz et al., (2013) revealed that the rootstocks had no noteworthy effects on juice volume of 'Rhode Red Valencia' and 'Valencia Late' oranges. They also reported that effects of the rootstocks in both scion cultivars on juice volume were seen to be of no consequence. Simón-Grao et al., (2014) found that 'Ellendale' resulted in highest amount of juice. They observed that 'Clementina Fina' and 'Clemenules' cultivars were the most suitable for a high volume of excellent value juice. Jaskarni et al., (2002) discovered that juice \%age was much better in diploid than triploid Kinnow. Zekri (2000) reported that juice content and soluble solids were advanced for Swingle citrumelo and Cleopatra mandarin than for the lemon rootstocks.

\section{f) Seed number}

Yildiz et al., (2013) revealed the effects of the rootstocks were insignificant in case of in number of seeds per fruit. Jaskarni et al., (2002) discovered more seeds in diploid Kinnow trees than triploid Kinnow.

\section{Biochemical parameters}

Various bio-chemical characters of the fruit like TSS, acidity and Vitamin-C were affected significantly by use of root stock (Wutscher and Hill, 1995).

\section{Total Soluble Solids ( ${ }^{0}$ Brix)}

Cantuarias-Aviles et al., (2010) found that in 'Sun Chu Sha Kat' and 'Sunki' mandarins and the 'Orlando' tangelo conferred smaller amounts of soluble solids. Dubey and Sharma (2016) revealed that RLC-4 and Karna Khatta shown better TSS in fruit juice. Benjamin et al., (2013) found TSS levels of all species were less in juice of fruits on Volkathan on Zekri et al., (2004) found maximum soluble solids on Citrus marophylla and Carrizo citrange accumulated the lowest soluble solids whereas Valencia trees yieldedmore soluble solids than Navel trees. Simón-Grao et al., (2014) found that 'Ellendale' produced the highest amount of juice, 'Nova' and 'Clementina Fina' showed high total soluble solids. McCollum et al., (2017) reported that rootstock effects on total solids were 
significant. Castle et al., (1988) revealed that plants budded on Trifoliate orange and Carrizo citrange exhibited better performance regarding TSS while lowest TSS was obtained from the plants grafted on Rough lemon species.

\section{Acidity (\%)}

Castle et al., (1988) confirmed that acidity is graft transmissible feature and influenced by rootstocks type and environmental conditions. Dubey and Sharma (2016) revealed that RLC4 and Karna Khatta shown better acid contents in the fruit juice.

Benjamin et al., (2013) found acidity levels were less in juice of fruits on Volka than on Yildiz et al., (2013) revealed that total acids (TA), Brix: TA ratio were seen to be insignificant.

Simón-Grao et al., (2014) found that 'Nova' and 'Clementina Fina' showed low titratable acidity. It was reported that some root stocks like sour orange, RLC-4, rough lemon and Karna Khatta including Troyer citrange promoted titratable acidity of lemon fruits. Differences in quality characteristics were due to different rootstocks (Yonemoto et al., 2005).

\section{TSS/acid ratio}

McCollum et al., (2017) reported rootstock effects on solids acid ratio were significant.

Waqar et al., (2006) reported that with increase in the ratio of TSS / acid ratio, there was a reduction in acidity so with less TSS / acid ratio, fruit quality is poor, and taste becomes watery and dull. Again, this ratio is used to determine the fruit maturity values, so where the ratio is more, the fruit will mature earlier. Zekri (2000) also reported that higher the Brix: acid ratio caused earlier maturation of the fruit.

\section{Vitamin-C}

Dubey and Sharma (2016) revealed that RLC4 and Troyer citrange proved their domination in terms of higher ascorbic acid content. Stuchi et al., (2008) reported cumulative yield and fruit quality of all cultivars were not influenced by the rootstocks. Parameshwar et al., (2018) exhibited t significant effect fruit quality of Valencia late like acidity (1.01\%) and ascorbic acid (57.86 mg/100 ml juice) was greatly improved in fruit tree that were budded on rough lemon rootstock.

\section{Plant nutrients}

Toplu et al., (2008) recommended use of Carrizo and Troyer citrange rootstocks for eastern mediterranean region citrus production as they had more ability to use more plant nutrient elements playing significant roles in production and quality. Substantial consequences of various rootstocks on uptake of $\mathrm{N}$ were also submitted previously in Fairchild mandarin (Fallahi and Rodney, 1992). Smith et al., (2004) and Dubey and Sharma (2016) discovered higher leaf nutrient $\mathrm{P}$ on Troyer citrange and lower levels on rough lemon root stock. Alike findings were revealed by Toplu et al., (2012) and Tsakelidou et al., (2002). But nonappearance of significant alterations between the mean $\mathrm{P}$ nutrient of leaves from most of the root-stocks was confirmed the earlier findings of Iyengar et al., (1982). There are contradictory discoveries in the literature regarding the influence of rootstocks on up taking of $\mathrm{Na}$ nutrient as Georgiou (2002) have reported that there was effect of rootstocks on uptake of $\mathrm{Na}$, whereas Toplu et al., (2012) found noteworthy incline in $\mathrm{Na}$ nutrient concentration of leaf micronutrients of rootstocks. Less quantity of foliar Mn on Troyer citrange rootstock was reported by Iyengar et al., (1982). It was also mentioned by Dubey and Sharma (2016) that alterations 
in foliar micronutrients were also submitted earlier due to rootstocks in various fruit crops (Fekete et al., 2012) which may differ with the nutrient's absorption capacities over roots (Marschner et al., 1986; Kayon, 2008).

In conclusion, rootstock should have good compatibility between both, scion and rootstock and have major effect in physical parameters like tree vigour, quality of the fruit, juice quality, yield as well as biochemical parameters like TSS, Acidity, Sugars, Vitamin C etc. depending upon environmental circumstances. At one time particular rootstock seems very appropriate but may completely failure in future. Under present situation no single rootstock is accessible that can be regarded as perfect for Kinnow mandarin species under all agroclimatic environments. Hence selection of appropriate rootstock for scion cultivar may lead to the success or failure of the citrus plantation. So judicious selection of rootstock leads to success of citrus plantation whereas wrong selection leads to decline.

\section{References}

Anon. (2007). Effect of rootstocks on yield and quality of Kinnow. Ann. Rep. 200607 AARI, Faisalabad. p. 60.

Benjamin, G., Tietel, Z., and Porat, R. (2013). Effects of rootstock/scion combinations on the flavor of citrus fruit. Journal of agricultural and food chemistry, 61(47), 11286-11294.

Bergmann, W., 1992. Colour Atlas Nutritional Disorders of Plants. Gustav Fischer, Verlag Jena.

Bielicki, P., Czynczyk, A., Bartosiewicz, B., (2006). Preliminary evaluation of apple tree cultivar 'Celeste' on dwarf rootstocks in Central Poland. Sodinink. Darzininkyste 25, 158-163.

Broadbent, P. and R. Sarooshi. (1993). Citrus rootstock evaluation. New South Wales,
Australia. Proc. 4th World Congress Intl. Soc. Citrus Nurserymen, South Africa: p. 242 -249.

Cantuarias-Aviles, T., Mourão Filho, F. D. A. A., Stuchi, E. S., da Silva, S. R., and Espinoza-Núñez, E. (2010). Tree performance and fruit yield and quality of 'Okitsu' Satsuma mandarin grafted on 12 rootstocks. Scientia Horticulturae, 123(3), 318-322.

Castle, W. S., Baldwin, J. C., and Muraro, R. P. (2010). Rootstocks and the performance and economic returns of 'Hamlin'sweet orange trees. Hort Science, 45(6), 875-881.

Castle, W.S., H.K. Wutscher, C.O. Youthsey and R.R. Pelosi. (1988). Citrumellos as rootstocks for Florida citrus. Proc. Fla. State Hort. Soc., 101: 28-33.

Cimen, B., Yesiloglu, T., Incesu, M., and Yilmaz, B. (2014). Growth and photosynthetic response of young 'Navelina'trees budded on to eight citrus rootstocks in response to iron deficiency. New Zealand Journal of Crop and Horticultural Science, 42(3), 170-182.

Dubey, A. K., and Sharma, R. M. (2016). Effect of rootstocks on tree growth, yield, quality and leaf mineral composition of lemon (Citrus limon (L.) Burm.). Scientia Horticulturae, 200, 131-136.

Espinoza-Nunez, E., Mourão Filho, F. D. A. A., Stuchi, E. S., Cantuarias-Avilés, T., and dos Santos Dias, C. T. (2011). Performance of 'Tahiti' lime on twelve rootstocks under irrigated and nonirrigated conditions. Scientia Horticulturae, 129(2), 227-231.

Fallahi, E., Rodney, D.R., (1992). Tree size, yield, fruit quality, and leaf mineral nutrient concentration of 'Fairchild' mandarin on six rootstocks. J. Am. Soc. Hortic. Sci. 117, 28-31.

Fekete, I., Rakonczas, N., Andrasi, D., Bodi, 
E., Kovacs, B., (2012). Effects of various grape rootstocks on macro and micro element uptake of 'Cserszegifuszeres' grape cultivar. Eur. Chem. Bull. 1, 524-527.

Forner-Giner, M. A., Hueso, J. J., Agüera, J. M., and Forner, J. B. (2010). Performance of Clausellina' mandarin on four rootstocks. Journal: Food, Agriculture and Environment (JFAE), 8, 328-331.

Georgiou, A. (2000). Performance of 'Nova' mandarin on eleven rootstocks in Cyprus. Scientia-Horticulturae, 84(1-2): 115-126.

Georgiou, A. (2009). Evaluation of rootstocks for the Cyprus local lemon variety 'Lapithkiotiki'. Scientia horticulturae, 123(2), 184-187.

Georgiou, A., (2002). Evaluation of rootstocks for Clementine mandarin in Cyprus. Sci. Hortic. 93, 29-38.

Hooker, J.D. (1872). Flora of British India. Reeve, and Co. London.

Hussain, S., Curk, F., Anjum, M. A., Pailly, O., and Tison, G. (2013). Performance evaluation of common clementine on various citrus rootstocks. Scientia Horticulturae, 150, 278-282.

Iyengar, B.R.V., Iyer, C.P.A., Sulladamath, V.V., (1982). Influence of rootstocks on the leaf nutrient composition of two scion cultivars of mandarin. Sci. Hortic. 16, 163-169.

Jaskarni, M. J., Khan, M. M., and Khan, I. A. (2002). Growth, morphology and fruit comparison of diploid and tetraploid Kinnow mandarin. Pakistan Journal of Agricultural Sciences, 39, 126-128.

Kayon, N., (2008). Variation for yield components in two winter sown lentil cultivars (Lens culninaris Medic). Bulg. J. Agric. Sci. 14, 460-465.

Kumar, H., G.S. Chohan and V.K. Vij. (1994). Studies on tree survival growth, yield and fruit quality of Pineapple cultivar of Sweet orange on different rootstocks. J. Res. Punj. Agric. Univ. India. 31(1): 27-31. (Hort. Absts., 66(3): 2596).

Legua, P., Bellver, R., Forner, J., and FornerGiner, M. A. (2011). Plant growth, yield and fruit quality of 'Lane Late' navel orange on four citrus rootstocks. Spanish Journal of Agricultural Research, 9(1), 271-279.

Lima, J.E.O. (1992). Observation on citrus blight in Sao Paulo, Brazil. Proc. Fla. State. Hort. Soc. 95:72 -75.

Mademba-Sy, F., Lemerre-Desprez, Z., and Lebegin, S. (2012). Use of flying dragon trifoliate orange as dwarfing rootstock for citrus under tropical climatic conditions. Hortscience, 47(1), 11-17.

Marschner, H., Romheld, V., Horst, W.J., Martin, P., 1986. Root induced changes in rhizosphere: Importance for the mineral nutrition of plants. $\mathrm{Z}$. Pflanzenernahr. Bondenk. 149 (441), 456.

McCollum, G., and Bowman, K. D. (2017). Rootstock Effects on Fruit Quality among 'Ray Ruby' Grapefruit Trees Grown in the Indian River District of Florida. HortScience, 52(4), 541-546

Niaz, A. C. and G. A. Chattha. (1994). Characteristics of some local and exotic citrus rootstocks. Pb. Fr. J. 47(1-4):2229.

Niaz, A.C., U. Hamid and I. M. Siddique. (1994). Observational trial on stock scion combination in Kinnow and Feutrell's Early. Pb. Fr. J. 47 (1-4): 5-9.

Parameshwar, P., Joshi, P. S., and Nagre, P. K. (2018). Effect of Rootstock on Plant Growth and Fruit Quality of Sweet Orange (Citrus sinensis var. Valencia late). Int. J. Curr. Microbiol. App. Sci, 7(4), 1685-1689.

Shafieizargar, A., Awang, Y., Juraimi, A. S., and Othman, R. (2012). Yield and fruit 
quality of'Queen'orange [Citrus sinensis (L) Osb.] grafted on different rootstocks in Iran. Australian Journal of Crop Science, 6(5), 777.

Shah, S. T., Rahman, S., Khan, N., Sajid, M., Rab, A., ul Amin, N. and Ahmad, R. (2016). Viability of meyer lemon over sour orange rootstock. Pure and Applied Biology, 5(2), 326.

Sharma, R.R. (2006). Fruit Production Problems and Solutions. Rootstock Problems and Solutions. Chap. 8. p. 205-212.

Sharma, R.R. and M. Srivastava. (2004). Plant Propagation and Nursery Management. Int. Book. Distributing, Lucknow, India. Chapter 5. p.270.

Simón-Grao, S., Gimeno, V., Simón, I., Lidón, V., Nieves, M., Balal, R. M. and García-Sánchez, F. (2014). Fruit quality characterization of eleven commercial mandarin cultivars in Spain. Scientia Horticulturae, 165, 274-280.

Singh, A., S.A.M.H. Naqvi and S. Singh. (2002). Citrus Rootstocks. Citrus Germplasm Cultivars and Rootstocks. Kalyani Publishers: p.102-123.

Smith, M.W., Shaw, R.G., Chapman, J.C., Owen-Turner, J., Slade Lee, L., Bruce McRae, K., Jorgensen, K.R., Mungomery, W.V., (2004). Long term performance of 'Ellendale' mandarin on seven commercial rootstocks in subtropical Australia. Sci. Hortic. 102, 7589.

Snokar, R.K. (2001). Citrus Rootstocks. Kalyani Publishers. p: 119-132.

Srivastav, M., Dubey, A.K., Sharma, R.R., (2005). Effect of rootstocks on leaf nutrient, tree growth, yield and fruit quality of sweet orange cv. Mosambi under Delhi conditions. Indian J. Agric. Sci. 75, 333-335.

Stuchi, E. S., Espinoza-Núñez, E., Mourão Filho, F. D. A. A., and Ortega, E. M. M. (2008). Vegetative growth, yield and fruit quality of four mandarin and hybrid cultivars on four rootstocks. Revista Brasileira de Fruticultura, 30(3), 741-747.

Tazima, Z. H., Neves, C. S. V. J., Yada, I. F. U., and Leite Júnior, R. P. (2013). Performance of' Okitsu' Satsuma Mandarin on nine rootstocks. Scientia Agricola, 70(6), 422-427.

Toplu, C., Kaplankiran, M., Demirkeser, T. H., and Yildiz, E. (2008). The effects of citrus rootstocks on Valencia Late and Rhode Red Valencia oranges for some plant nutrient elements. African Journal of Biotechnology, 7(24).

Toplu, C., Uygur, V., Kaplankıran, M., Demirkeser, T.H., Y1ld1z, E., (2012). Effect of citrus rootstocks on leaf mineral composition of 'Okitsu', 'Clausellina', and Silverhill' mandarin cultivars. J. Plant Nutr. 35, 1329-1340.

Tsakelidou, K., Papanikolaou, X., Protopapadakis, E., (2002). Rootstock effects on then yields, tree and fruit characteristics of the mandarin cultivar 'Clementine' on the Island of Rhodes. Exp. Agric. 38, 351-358.

Waqar Ahmed, M.A. Pervez, M. Amjad, M. Khalid, C. M. Ayyub and M. Azher Nawaz (2006).effect of stionic combination on the growth and yield of kinnow mandarin (Citrus reticulata BLANCO). Pak. J. Bot., 38(3): 603612.

Wutscher, H.K. and L.L. Hill. (1995). Performance of 'Hamlin' orange on 16 rootstocks in East central Florida. Hort. Sci., 30(1): 41-43.

Yildiz, E., HakanDemirkeser, T., and Kaplankiran, M. (2013). Growth, yield, and fruit quality of 'Rhode Red Valencia' and 'Valencia Late' sweet oranges grown on three rootstocks in eastern Mediterranean. Chilean journal of agricultural research, 73(2), 142146. 
Yonemoto, Y., Takahara, T., Okuda, H., Ogata, T., (2005). Effects of 'Karatachi, common trifoliate orange (Poncirus trifoliata (L.) Raf.) and 'Hiryu' Flying Dragon trifoliate orange $(P$. trifoliata var. monstrosa) rootstocks on tree growth, yield and fruit qualities in young tree of new citrus cultivars 'Amakusa' and 'Amaka'. Hortic. Res. 4, 81-84.

Zekri, M. (2000). 594 Citrus Rootstocks
Affect Scion Nutrition, Fruit Quality, Growth, Yield, and Economical Return. Hort Science, 35(3), 499-499.

Zekri, M. (2000). Evaluation of Orange Trees Budded on Several Rootstocks and Planted at High Density on Flatwoods Soil. Proc. Fla. State Hort. Soc., 113

Zekri, M., and Al-Jaleel, A. (2004). Evaluation of rootstocks for Valencia and Navel orange trees in Saudi Arabia. Fruits, 59(2), 91-100.

\section{How to cite this article:}

Sukhdip Singh, Jatinder Singh and Anis Mirza. 2019. Evaluation of Mandarin Cultivars on Different Root Stocks-A Review. Int.J.Curr.Microbiol.App.Sci. 8(01): 1213-1222.

doi: https://doi.org/10.20546/ijcmas.2019.801.128 